\title{
Communication/Comunicação
}

\section{Could leprosy reaction episodes be exacerbated by oral infections?}

\author{
Episódios reacionais da hanseníase podem ser exacerbados por infecções orais?
}

\section{Ana Carolina Fragoso Motta ${ }^{1}$, Renata Bazan Furini' ${ }^{2}$, João Carlos Lopes Simão ${ }^{2}$, Mariana Bellini Vieira ${ }^{2}$, Maria Aparecida Nunes Ferreira ${ }^{2}$, Marilena Chinali Komesu ${ }^{1}$ and Norma Tiraboschi Foss ${ }^{2}$}

\begin{abstract}
Introduction: This study evaluated whether leprosy reactions could be associated with oral infection. Methods: Leprosy patients $(\mathrm{n}=38)$ with (Group I) and without (Group II) oral infections were selected. Reactions were identified from the clinical and histopathological features associated with serum C-reactive protein (CRP) and 10kDa interferon-gamma-induced protein (IP-10) levels, determined before and after elimination of the foci of infection. Results: Group I presented more reactions than group II did, and improvement of the reactions after dental treatment. Serum CRP and IP-10 did not differ before and after the dental treatment, but differed between the groups. Conclusions: Oral infection could be an exacerbating factor in leprosy reactions.
\end{abstract}

Keywords: Leprosy reaction episodes. Oral infection. Inflammatory markers.

\section{RESUMO}

Introdução: Este estudo avaliou se as reações hansênicas podem estar associadas a infecções orais. Métodos: Pacientes com hanseníase $(\mathrm{n}=38)$ com (Grupo I) e sem (Grupo II) infecções orais foram selecionados. As reações foram identificadas pelas características clínicas, histopatológicas, associadas a proteína-C-reativa (PCR) e proteína indutora de interferongamma de 10kDa (IP-10) séricos determinados antes e após a eliminação dos focos de infecção. Resultados: Grupo I apresentou mais reações que o grupo II, e melhora das reações após o tratamento odontológico. PCR e IP10 séricos não diferiram antes e após o tratamento odontológico, entretanto diferiram entre os grupos. Conclusões: As infecções orais podem ser exacerbadores das reações hansênicas.

Palavras-chaves: Episódios reacionais da hanseníase. Infecções orais. Marcadores inflamatórios.

Reactional episodes are a serious problem during the course of leprosy since they may be responsible for much of the permanent nerve damage, thus leading to disability and deformities ${ }^{1}$. These episodes represent an exacerbation of the inflammatory process that can occur before, during or after leprosy treatment [multidrug therapy/World Health Organization (MDT - WHO) $]^{2,3}$. There are two well recognized main types of reaction: reversal reaction (RR) and erythema nodosum leprosum (ENL). Reversal reactions may be due to an increase in the cell-mediated response to Mycobacterium leprae characterized by a Th1 response. Erythema nodosum leprosum

1. Department of Morphology, Stomatology and Physiology, Ribeirão Preto Dental School, University of São Paulo, Ribeirão Preto, SP. 2. Division of Dermatology, Department of Internal Medicine, Ribeirão Preto Medical School, University of São Ribeirão Preto, SP.

Address to: Dra. Ana Carolina Fragoso Motta. Dept ${ }^{\circ}$ Morfologia, Estomatologia e Fisiologia/FORP/USP. Av. do Café s/n, 14040-904 Ribeirão Preto, SP, Brasil.

Phone/Fax: 55 16 3633-0236

e-mail: anacfm@usp.br

Received in 12/08/2010

Accepted in 26/10/2010 is a systemic inflammatory process characterized by intralesional neutrophilic infiltration and by a Th2 response ${ }^{3,4}$. Since both types of reaction are accompanied by increased release of the inflammatory markers ${ }^{5-7}$, it is reasonable to consider the possibility that these episodes may be associated with an infectious process, such as dental abscess or periodontal diseases. These may induce overstimulation of the host immune system through the release of numerous inflammatory markers, including cytokines, acute-phase proteins and chemokines ${ }^{8-10}$. The present study aimed to determine whether the presence of leprosy reaction episodes might be associated with dental and periodontal infection, and to determine the serum C-reactive protein (CRP) and IP-10 levels before and after the elimination of oral infections in leprosy patients.

We selected 38 leprosy patients ( 29 men and 9 women; mean age \pm SD: $43.92 \pm 2.12$ years; range $18-81$ years) with and without oral infection (OI) before, during or after specific leprosy treatment. These patients were divided into two groups: group I consisted of leprosy patients presenting some oral infections, and group II consisted of leprosy patients without oral infections. The diagnosis of leprosy was made based on clinical and histopathological findings, and on the Ridley \& Jopling classification ${ }^{11}$, bacilloscopy, biopsy and determination of the presence of antibodies to phenolic glycolipid-1 (anti-PGL-1). The oral infections considered were: periodontal diseases (PD), irreversible pulpitis (IP), pulpal necrosis (PN) and inflammatory periapical lesions (IPL). Subjects were excluded if they presented a coexisting local or systemic infection or diabetes mellitus, or if they had received antimicrobial treatment for any infections over the previous six months. The trial was approved by the local Ethics Committee and all subjects gave written informed consent to participate.

After the patients had been diagnosed with leprosy and oral disease, the patients in both study groups (I and II) were instructed about oral hygiene techniques and supragingival prophylaxis and the patients in group I were treated for their dental and/or periodontal diseases. The patients were reexamined seven days after completing the treatment for the dental and/or periodontal disease (group I) or after the dental prophylaxis (group II). The analysis criteria were based on clinical features such as the presence of reactional episodes (determined by a blinded examiner), and on laboratory tests such as blood counts, urine assay, determination of CRP levels and serum quantification of $10 \mathrm{kDa}$ interferon-gamma-induced protein (IP-10) levels by means of ELISA. Care was taken to maintain the same systemic treatment during the analysis in order to avoid drug-related variables. The severity of the reactional episodes was determined on the basis of the symptoms and the degree of clinical skin manifestations and peripheral nerve involvement presented 
by each patient between the two data collection times. Mean CRP and serum IP-10 were calculated for each patient, as well as for each group. The results from the two groups were compared using the Mann-Whitney test, and baseline values (before) were compared with those obtained seven days later, by means of the Wilcoxon ranksum test with the aid of the GraphPad Prism software (San Diego, CA, USA). Significance was set at $\mathrm{p}<0.05$.

Group I consisted of 19 leprosy patients ( 13 men and 6 women; mean age $45.05 \pm 6.3$ years; range $18-72$ years) presenting some oral infections: seven patients presented dental diseases (IP, PN and IPL), three presented PD and nine presented a combination of dental diseases and PD. In this group, nine patients presented lepromatous leprosy (LL), five were borderline lepromatous (BL), three were borderline borderline (BB) and two were borderline tuberculoid (BT). Group II consisted of 19 patients ( 16 men and 3 women; mean age $42.8 \pm 13.4$ years; range $21-81$ years) without oral infections. In this group, four patients presented $\mathrm{LL}$, one $\mathrm{BL}$, one $\mathrm{BB}$, nine $\mathrm{BT}$ and four, the tuberculoid (TT) form. Fifteen (78.9\%) of the 19 patients in group I presented ENL at the time of diagnosis, three (15.8\%) had reversal reactions (two BT and one BL patient) and only one (5.3\%) patient did not present reactional episodes. After the dental and/or periodontal disease had been treated, 68.4\% (13/19) of Group I patients presented a clinical improvement in reactional episodes, as determined by decreases in skin lesions and symptoms, whereas no clinical change was detected in Group II.

C-reactive protein and IP-10 levels did not differ significantly between before and after dental treatment in group I, even though they tended to become reduced after dental and periodontal treatment. No differences were observed between the two data collection times regarding clinical findings or any monitored mediators in group II. Serum CRP levels (at baseline) and IP-10 levels (at baseline and seven days after OI control) were significantly higher in group I than in group II (Figures $\mathbf{1}$ and $\mathbf{2}$ ).

This study attempted to clarify whether chronic OI could represent a maintenance factor in leprosy reaction episodes. A relationship between focal infection and dermatoses such as psoriasis ${ }^{12}$ and atopic dermatitis ${ }^{13}$ has been reported, but none concerning reactional episodes. It was observed that ENL was more

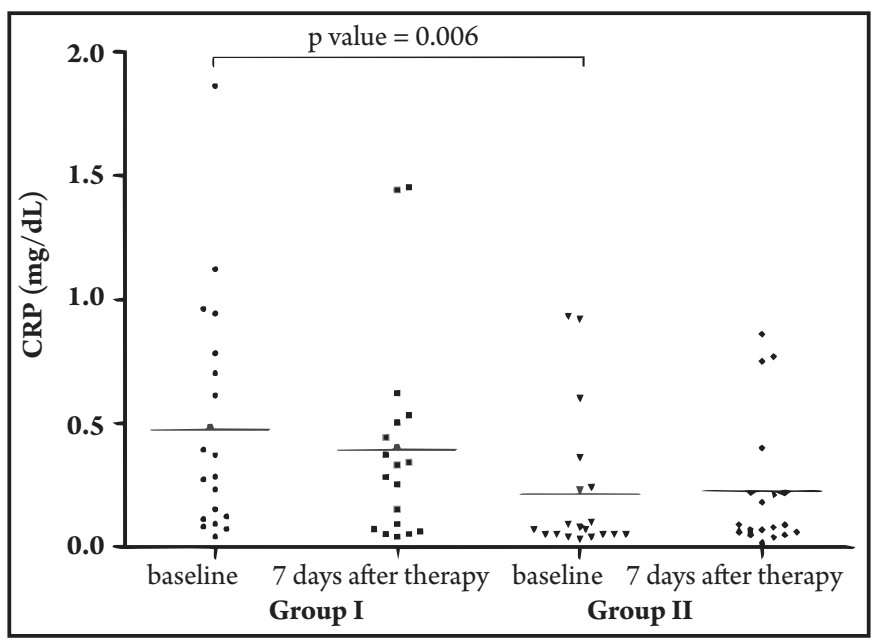

FIGURE 1 - Serum C-reactive protein levels of leprosy patients presenting chronic oral infections (Group I) and of leprosy patients without oral infection (Group II) before and after chronic oral infection therapy. frequent in patients with OI (78.9\%) than in patients with absence of OI (15.2\%). This may have been due to the fact that the elevation in inflammatory marker expression by cells in the presence of OI can cause a spillover of these markers into the circulation, where they can act as a maintenance factor in leprosy reactions, as described for other diseases ${ }^{7,8,12,13}$.

After OI treatment, there was an improvement of clinical symptoms in $68.4 \%(13 / 19)$ of the patients in group I. In addition, there was an improvement in all of the periodontal clinical parameters monitored. However, no improvement was detected in peripheral serum levels of CRP or IP-10. The period of seven days after OI treatment was probably not sufficient to determine whether there were any decreases in serum CRP and IP-10 levels, although there was a tendency towards a reduction (Figures $\mathbf{1}$ and $\mathbf{2}$ ).

We found a significantly higher CRP level in patients with OI than in patients without these infections at baseline $(p=0.006)$. No statistically significant difference in serum CRP levels was observed between the two groups after OI therapy. We believe that CRP may be a diagnostic biomarker of interest, although the significance of this finding should be considered with caution since CRP is a general inflammatory marker.

Similarly to CRP, we found higher levels of IP-10 in patients with OI than in patients without these infections $(\mathrm{p}=0.001)$. This may be related to the activity of IP-10, which attracts Th1 cells as a delayed hypersensitivity response $\mathrm{e}^{14}$. Furthermore, IP-10 expression induced by IFN $\gamma$ has been demonstrated in the skin of a leprosy patient 24 hours after administration of the classic purified protein derivative of tuberculin ${ }^{10}$. Thus, during the inflammatory reaction of the ENL, the increases in serum CRP and IP-10 may be associated with higher cell activity and with some bacterial destruction, as determined by peripheral inflammatory manifestations.

Since most of the patients with OI presented reactional episodes (78.9\%) and showed higher serum CRP and IP-10 levels than those without OI, these findings suggest that OI may have stimulated the inflammatory reaction. Studies with a larger sample are needed in order to support this observation, because dental treatment may improve the care for leprosy patients and help prevent disability caused by leprosy reactions.

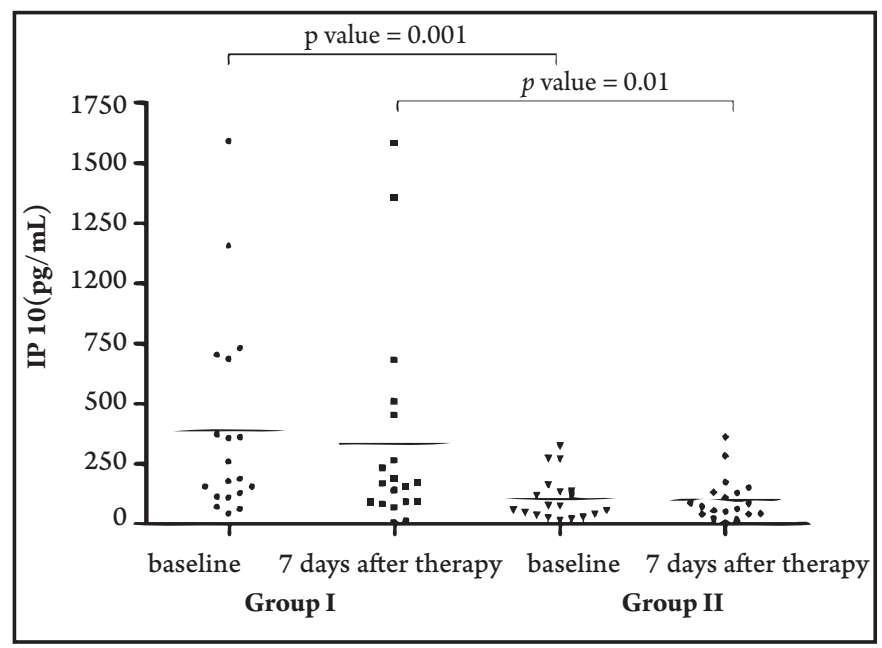

FIGURE 2 - Serum IP-10 levels of leprosy patients presenting chronic oral infections (Group I) and of leprosy patients without oral infection (Group II) before and after oral infection therapy. 
We thank Mr Mario Ignácio Neto for assistance with sample analysis.

\section{CONFLICT OF INTEREST}

The authors declare that there are no conflict of interest.

\section{FINANCIAL SUPPORT}

National Council for Scientific and Technological Development (CNPq) (grant 154806/2006-4), São Paulo State Foundation against Leprosy (grant 110) and the Teaching, Research and Assistance Support Foundation of HCFMRP-USP (FAEPA).

\section{REFERENCES}

1. Jopling WH. Classification of reaction in leprosy. Leprosy Rev 1970; 41:62-63.

2. Seghal VN, Sharma V. Reactions in leprosy - a prospective study of clinical, bacteriological, immunological and histopathological parameters in thirty-five Indians. J Dermatol 1998; 15:412-419.

3. Rea TH, Modlin RL. Immunopathology of leprosy skin lesions. Semin Dermatol 1991; 10: 188-193.

4. Cuevas J, Rodríguez-Peralto JL, Carrillo R, Contreras F. Erythema nodosum leprosum: reactional leprosy. Sem Cutan Med Surg 2007; 26:126-130.

5. Foss NT, Oliveira EB, Silva CL. Correlation between TNF production, increase of plasma C-reactive protein level and suppression of $\mathrm{T}$ lymphocyte response to concanavalin A during erythema nodosum leprosum. Int J Lepr Other Mycobact Dis 1993; 61:218-226.

6. Silva EA, Iyer A, Ura S, Lauris JR, Naafs B, Das PK, et al. Utility of measuring serum levels of anti-PGL-1 antibody, neopterin and C-reactive protein in monitoring leprosy patients during multi-drug treatment and reactions. Trop Med Int Health 2007; 12:1450-1458.

7. Jeffcoat MK, Geurs NC, Reddy MS, Cliver SP, Goldenberg RL, Hauth JC. Periodontal infection and preterm birth: results of a prospective study. J Am Dent Assoc 2001; 132:875-880.

8. Rodrigues DC, Taba MJ, Novaes AB, Souza SL, Grisi MF. Effect of non-surgical periodontal therapy on glycemic control in patients with type 2 diabetes mellitus. J Periodontol 2003; 74:1361-1367.

9. Motta AC, Furini RB, Simão JC, Ferreira MA, Komesu MC, Foss NT. The recurrence of leprosy reactional episodes could be associated with oral chronic infections and expression of serum IL-1, TNF- $\alpha$, IL-6, IFN- $\gamma$ and IL-10. Braz Dent J 2010; 21:158-164.

10. Kaplan G, Luster AD, Hancock G, Cohn ZA. The expression of a $\gamma$ interferoninduced protein (IP-10) in delayed immune responses in human skin.J Exp Med 1987; 166:1098-1108.

11. Ridley DS, Jopling WH. Classification of leprosy according to immunity: a fivegroup system. Int J Lepr Other Mycobact Dis 1966; 34:255-273.

12. Mizutani H, Ohmoto Y, Mizutani T, Murata M, Schimizu M. Role of increased production of monocytes TNF-alpha, IL-1 beta and IL-6 in psoriasis: relation to focal infection, disease activity and responses to treatments. J Dermatol Sci 1997; 14:145-153.

13. Igawa K, Nishioka K, Yokozeki H. Odontogenic focal infection could be partly involved in the pathogenesis of atopic dermatitis as exacerbating factor. Int J Dermatol 2007; 46:376-379.

14. Araujo-Stefani MM, Guerra JG, Souza ALM, Costa MB, Oliveira ML, Martelli CT, et al. Potential plasma markers of type 1 and type 2 leprosy reactions: a preliminary report. BMC Infect Dis 2009; 9:1-8. 